Original Research

\title{
Development of the Mind-Body-Spiritual Nursing Care Model (MBS) for Coronary Heart Disease Patients
}

\section{Ninuk Dian Kurniawati ${ }^{1}$, Nursalam Nursalam ${ }^{1}$ and Suharto Suharto ${ }^{2}$}

1 Faculty of Nursing, Universitas Airlangga, Surabaya, Indonesia

2 Faculty of Medicine, Universitas Airlangga, Surabaya, Indonesia

\begin{abstract}
Introduction: Patients with coronary heart disease (CHD) may experience various physical, psychological or spiritual issues. A holistic mind-body spiritual nursing care (MBS) model is needed to help patients' cope with the issues. This study aimed to develop an MBS nursing care model for CHD patients.

Method: The study employed a crossectional design with 110 CHD patients participated in the study. Respondents were asked to fill out questionnaires to gather the required data. Criteria for respondent selection were Moslem, aged 40-75 year, medical diagnosis of CHD, and haemodynamically stable. The independent variables were focal, contextual and residual stimuli, while the dependent variables were coping and spirituality. Data were analyzed using partial least square.
\end{abstract}

Results: The results show that the mind-body-spiritual nursing care formed focal stimuli. Spirituality is formed by focal, contextual, residual stimuli and coping style. Nursing care significantly affects spirituality, shown by T-statistics of 6.795. Spirituality can be explained by patience, endeavour toward wellness, and offer the results only to the God by $72 \%$, while the rest is explained by other factors.

Conclusion: MBS nursing care model has a strong relationship with spirituality. This model needs to be applied in a further research to see its effectiveness in improving spirituality and expression of cardiovascular risk inflammatory markers.

\section{ARTICLE HISTORY}

Received: November 17, 2017

Accepted: October 02, 2018

\section{KEYWORDS}

coronary heart disease; mind-body-spiritual; nursing care model; spirituality

\section{CONTACT}

Ninuk Dian Kurniawati $\triangle$ ninuk.dk@fkp.unair.ac.id $\fallingdotseq$ Faculty of Nursing, Universitas Airlangga, Surabaya, Indonesia

Cite this as: Kurniawati, N., Nursalam, N., \& Suharto, S. (2018). Development of the Mind-Body-Spiritual (MBS) Nursing Care Model for Coronary Heart Disease Patients. Jurnal Ners, 13(2), 144-149. doi:http://dx.doi.org/10.20473/in.v13i2.6607

\section{INTRODUCTION}

A provision of a mind-body-spiritual nursing care that emphasizes not only on physical aspect of care, but also psychological, and spiritual care are needed. However, a fit of a model of nursing care for patients treated in hospital has yet to be developed, hence, it is necessary to develop the mind-body-spiritual nursing care model.

Being treated in the hospital with the acute coronary syndrome can be very distressfull for patients, on several aspects. A qualitative study revealed that patients' experiencing multiple issues during hospital stays and need help from nurses to help them cope with the issues (Kurniawati, Nursalam, \& Suharto, 2017). Stress has been empirically shown to interfere with immunity, mainly through a so-called hypothalamus-pituitary- adrenal (HPA) axis. After the brain perceives the stressor, the hypothalamus releases corticotropinreleasing hormone ( $\mathrm{CRH})$, which then stimulates the pituitary gland to release ACTH. This will, in turn, causes the adrenal cortex to express glucocorticoids.

Several studies have investigated the mind-body, spiritual intervention, but current research has not incorporated mind-body-spiritual intervention comprehensively in a series of nursing orders. Psychological interventions proved to be effective in improving pain tolerance and postoperative immunologic resistance (Rehatta, 2005), reducing postoperative pain, anxiety, tension and analgesic use in 20 studies involving a total of 1297 patients (Nelson et al., 2013) and decreasing physical symptoms and mental in patients with chronic physical and mental pain, (Vranceanu et al., 2014). 
In addition to the mind-body intervention, studies have demonstrated the benefits of spiritualbased intervention in increasing HSP 72 (Asiyah, Putra, \& Kuntoro, 2011), increasing alpha waves in the brain and decreasing cortisol levels, decreasing stress and anxiety (Barnby, Bailey, Chambers, \& Fitzgerald, 2015), decreasing depression in patients with acute coronary syndrome (Warber et al., 2011), and lowering the cortisol levels of HIV patients (Murray et al., 2007).

Therefore, the literature review supports the promising benefits of a comprehensive mind-bodyspiritual nursing care intervention for CHD patients. This study aimed at developing a mind-bodyspiritual nursing care for coronary heart disease patients treated at hospitals. This is supported by the previously described literature review that highlights the promising benefits of the mind-bodyspiritual nursing care for the patients that until to date, is yet to be developed.

\section{MATERIALS AND METHODS}

The research used an analytical explanatory design where required data were taken cross-sectionally approximately over six months period. The population of the study was all patients with coronary heart disease hospitalised in some hospitals in Surabaya, Indonesia. The sample was drawn from the population treated at various rooms in a top-referral-government-owned hospital in Eastern Indonesia, a university hospital and a big private hospital in Surabaya. The inclusion criteria were CHD patients with a stable hemodynamic status had been treated for at least two days and had a capacity to understand written information; whereas the exclusion criteria were CHD patients with decreased level of consciousness and withdrew from the study for many reasons. Participants of the study were selected randomly by simple random sampling.

The sample size was calculated using statistical power and effect size adjusted to SEM-PLS model sample size table from Sholihin \& Ratmono (2013). Based on the preliminary model which consist of four big arrows, significant at 5\% and minimum R2 of 0.50 , the minimum sample size yielded from the table was 42 . Thus, the number of respondents in this study was 110 respondents.

Data were collected from February to April 2017 using questionnaires developed from a previous study (Kurniawati et al., 2017) in 2017. Questionnaires were tested for validity and reliability and they were all valid and reliable with $r$ $=0,508-951, p=0,008-0,000$, and Cronbach alfa between 0,638-927. All subjects were required to fill out the questionnaires once cross-sectionally and there was no follow up conducted by the authors. The collected data were tabulated and analysed using statistical analysis of Smart Partial Least Square with aimed to develop a statistical model of MBS nursing care.
The study protocols were reviewed and approved by Commissions of Ethics from Rumah Sakit Universitas Airlangga Number 023 / KEH / 2016, dated August 6, 2016, and RSUD Dr. Soetomo Number 262 / Panke.KKE / IV / 2017, dated April 6, 2017.

\section{RESULTS}

Table 1 shows participants' demographic data. It can be seen from the table 1 that the majority of respondents are male (68.18\%), Javanese (82.73\%), from Surabaya (54.5\%), with medical diagnosis of STEMI (42.73\%), underwent second hospitalisation (51\%), aged 56-70 years (54.55\%) and on their third day of hospital stay (43.64\%).

Variables examined in this study were focal stimuli (X1), contextual stimuli (X2), residual stimuli (X3), coping (Y1) and spirituality (Y2). The focal stimuli depicted by Patient's issues (X1.1) and the Mind-Body-Spiritual Nursing Care (X1.2). The contextual stimuli had 3 indicators: Hospital Environment (X2.1), Family Support (X2.2), and Past Hospitalisation Experience (X2.3). Residual stimuli were measured through four aspects of indicators: education (X3.1), occupation (X3.2), health insurance (X3.3) and patients' religious rituals (X3.4). Coping was measured through two indicators: problemfocused coping (Y1.1) and emotional-focused coping (Y1.2). Lastly, Spirituality was defined by patients

Table 1. Characteristics of Respondents

\begin{tabular}{|c|c|c|c|}
\hline Variables & Sub Variables & Frequency & $\%$ \\
\hline \multirow{2}{*}{ Sex } & Men & 75 & 68.18 \\
\hline & Women & 35 & 31.82 \\
\hline \multirow{8}{*}{ Ethnicity } & Banjar & 2 & 1.82 \\
\hline & Batak & 3 & 2.73 \\
\hline & Javanese & 91 & 82.73 \\
\hline & Madurese & 7 & 6.36 \\
\hline & Buginese & 1 & 0.91 \\
\hline & Malay & 2 & 1.82 \\
\hline & Sasak & 1 & 0.91 \\
\hline & Sundanese & 3 & 2.73 \\
\hline \multirow{6}{*}{ Address } & East Java & 97 & 88.18 \\
\hline & Borneo & 2 & 1.8 \\
\hline & Madura & 8 & 7.3 \\
\hline & West Nusa & & \\
\hline & Tenggara & 2 & 1.8 \\
\hline & Papua & 1 & 0.9 \\
\hline \multirow{4}{*}{ Age } & $40-50$ & 28 & 22.45 \\
\hline & $51-60$ & 47 & 42.73 \\
\hline & $61-70$ & 35 & 31.82 \\
\hline & Angina, UAP & 23 & 20.91 \\
\hline \multirow{4}{*}{$\begin{array}{l}\text { Medical } \\
\text { Diagnosis }\end{array}$} & NSTEMI & 13 & 11.82 \\
\hline & STEMI & 47 & 42.73 \\
\hline & OMI & 22 & 20.00 \\
\hline & Iskemia & 5 & 4.55 \\
\hline \multirow{3}{*}{$\begin{array}{l}\text { Number of } \\
\text { hospitalisa } \\
\text { tion }\end{array}$} & 1 & 32 & 29.09 \\
\hline & 2 & 51 & 46.36 \\
\hline & 3 & 27 & 24.55 \\
\hline \multirow{4}{*}{$\begin{array}{l}\text { Length of } \\
\text { hospital } \\
\text { stay }\end{array}$} & 1 & 5 & 4.55 \\
\hline & 2 & 28 & 25.45 \\
\hline & 3 & 48 & 43.64 \\
\hline & 4 & 29 & 26.36 \\
\hline
\end{tabular}


Table 2. Distribution of Respondents of Children and Caregivers Meeting the Research Criteria at YPAC Surakarta March-April $2017(\mathrm{n}=23)$

\begin{tabular}{|c|c|c|c|c|c|c|c|c|c|c|c|c|}
\hline \multirow{3}{*}{ Variable } & \multirow{3}{*}{ Indicator } & \multirow{3}{*}{ Sub Indicator } & \multicolumn{10}{|c|}{ Category } \\
\hline & & & \multicolumn{2}{|c|}{ Never } & \multicolumn{2}{|c|}{ Sometimes } & \multicolumn{2}{|c|}{ Often } & \multicolumn{2}{|c|}{ Always } & \multicolumn{2}{|c|}{ Total } \\
\hline & & & $\mathbf{n}$ & $\%$ & $\mathbf{n}$ & $\%$ & $\mathbf{n}$ & $\%$ & $\mathbf{n}$ & $\%$ & $\mathbf{n}$ & $\%$ \\
\hline \multirow{8}{*}{$\begin{array}{l}\text { Focal } \\
\text { stimuli }\end{array}$} & \multirow{4}{*}{$\begin{array}{l}\text { Patients's } \\
\text { issue }\end{array}$} & Physical & 4 & 3.64 & 24 & 21.82 & 55 & 50.00 & 27 & 24.55 & 110 & 100 \\
\hline & & Psychological & 46 & 41.82 & 36 & 32.73 & 27 & 24.55 & 1 & 0.91 & 110 & 100 \\
\hline & & Social & 71 & 64.55 & 31 & 28.18 & 8 & 7.27 & 0 & 0.00 & 110 & 100 \\
\hline & & Spiritual & 23 & 20.91 & 67 & 60.91 & 18 & 16.36 & 2 & 1.82 & 110 & 100 \\
\hline & \multirow{4}{*}{$\begin{array}{l}\text { MBS nursing } \\
\text { care }\end{array}$} & Assess & 4 & 3.64 & 15 & 6.82 & 46 & 20.91 & 155 & 70.45 & 220 & 100 \\
\hline & & $\begin{array}{l}\text { Help meet the patient's physical } \\
\text { need }\end{array}$ & 2 & 1.82 & 14 & 6.36 & 44 & 20.00 & 160 & 72.73 & 220 & 100 \\
\hline & & Fascilitate the coping strategy & 37 & 33.64 & 10 & 4.55 & 48 & 21.82 & 125 & 56.82 & 220 & 100 \\
\hline & & Fascilitate & 47 & 42.73 & 11 & 5.00 & 68 & 30.91 & 94 & 42.73 & 220 & 100 \\
\hline \multirow{8}{*}{$\begin{array}{l}\text { Contextual } \\
\text { stimuli }\end{array}$} & \multirow{3}{*}{$\begin{array}{l}\text { Hospital } \\
\text { environment }\end{array}$} & Comfortness & 2 & 0.61 & 36 & 10.91 & 119 & 36.06 & 173 & 52.42 & 330 & 100 \\
\hline & & Nurse's communication & 0 & 0.00 & 15 & 6.82 & 62 & 28.18 & 143 & 65.00 & 220 & 100 \\
\hline & & Nurs & 0 & 0.00 & 33 & 15.00 & 63 & 28.64 & 124 & 56.36 & 220 & 100 \\
\hline & \multirow{3}{*}{$\begin{array}{l}\text { Family } \\
\text { support }\end{array}$} & Emotional suppport & 2 & 0.91 & 17 & 7.73 & 78 & 35.45 & 123 & 55.91 & 220 & 100 \\
\hline & & DuCognitive suppport & 6 & 2.73 & 34 & 15.45 & 54 & 24.55 & 126 & 57.27 & 220 & 100 \\
\hline & & Material suppport & 2 & 0.91 & 27 & 12.27 & 73 & 33.18 & 118 & 53.64 & 220 & 100 \\
\hline & \multirow{2}{*}{$\begin{array}{l}\text { Past } \\
\text { experience }\end{array}$} & Satisfaction toward nursing care & 89 & 40.45 & 48 & 21.82 & 71 & 32.27 & 12 & 5.45 & 220 & 100 \\
\hline & & $\begin{array}{l}\text { Effectiveness of previous coping } \\
\text { style }\end{array}$ & 124 & 56.36 & 40 & 18.18 & 48 & 21.82 & 8 & 3.64 & 220 & 100 \\
\hline \multirow[t]{8}{*}{ Coping } & \multirow{4}{*}{$\begin{array}{l}\text { Problem } \\
\text { focused } \\
\text { coping }\end{array}$} & Planned-problem solving & 12 & 5.45 & 52 & 23.64 & 65 & 29.55 & 91 & 41.36 & 220 & 100 \\
\hline & & Direc & 4 & 1.82 & 34 & 15.45 & 98 & 44.55 & 84 & 38.18 & 220 & 100 \\
\hline & & Seeking help & 3 & 1.36 & 31 & 14.09 & 96 & 43.64 & 90 & 40.91 & 220 & 100 \\
\hline & & Information seeking & 3 & 1.36 & 27 & 12.27 & 77 & 35 & 113 & 51.36 & 220 & 100 \\
\hline & Emotional & Avoidance & 61 & 27.73 & 129 & 58.64 & 19 & 8.64 & 11 & 5 & 220 & 100 \\
\hline & Focused & Deny & 61 & 27.73 & 123 & 55.91 & 21 & 9.55 & 15 & 6.82 & 220 & 100 \\
\hline & Coping & Self-criticsm & 131 & 59.55 & 45 & 20.45 & 31 & 14.09 & 13 & 5.91 & 220 & 100 \\
\hline & & Look for silver lining & 26 & 11.82 & 81 & 36.82 & 78 & 35.45 & 35 & 15.91 & 220 & 100 \\
\hline \multirow[t]{3}{*}{ Spirituality } & \multicolumn{2}{|l|}{ Patience } & 0 & 0 & 30 & 9.09 & 103 & 31.21 & 197 & 59.70 & 330 & 100 \\
\hline & \multirow{2}{*}{\multicolumn{2}{|c|}{ Endevour }} & 11 & 3.33 & 11 & 3.33 & 98 & 29.7 & 210 & 63.64 & 330 & 100 \\
\hline & & & 0 & 0 & 17 & 5.15 & 98 & 29.70 & 215 & 65.15 & 330 & 100 \\
\hline
\end{tabular}

Table 3. Description of Residual Stimuli

\begin{tabular}{llcc}
\hline \multicolumn{1}{c}{ Indicator } & \multicolumn{1}{c}{ Sub Indicator } & n & \% \\
\hline \multirow{3}{*}{ Education } & Non/elementary & 26 & 23.64 \\
& High school & 50 & 45.45 \\
& Diploma & 7 & 6.36 \\
& $\geq$ S1 & 27 & 24.55 \\
Occupation & Lone/housewife & 16 & 14.55 \\
& Eabor, retirement, farmer, driver & 27 & 24.55 \\
Health insurance & Goverment employee & 57 & 51.82 \\
& Govt health insurance class III & 10 & 9.09 \\
& Govt health insurance class II & 5 & 4.55 \\
Religious rituals & Govt health insurance class I & 45 & 40.91 \\
& Private insurance & 55 & 50.00 \\
& Never & 5 & 4.55 \\
& Sometimes & 0 & 0 \\
& Often & 5 & 4.55 \\
& Always & 40 & 36.36 \\
\end{tabular}

during illness, endeavour toward wellness, and a total submission toward the God's will.

Table 2 summarises the data of focal and contextual stimuli. Based on the table it can be concluded that the majority of respondents used a problem-focused coping style, rather than emotional-focused coping style with seeking information reported being the highest proportion (51.36\%). The most common coping style was under emotional focused coping style that respondents never used was self-criticism (59.55\%). Most respondents reported always being patient (59.7\%), endeavouring toward wellness (63.64\%), and offering all the result of the treatment to God (65.15\%).

After the outer model was defined, the inner model was then analysed. The purpose of structural model analysis (Inner Model) was to examine the influence of exogenous factors on endogenous factors. The value used as a reference was the T- 
Table 2. Convergent validity of the latent variables

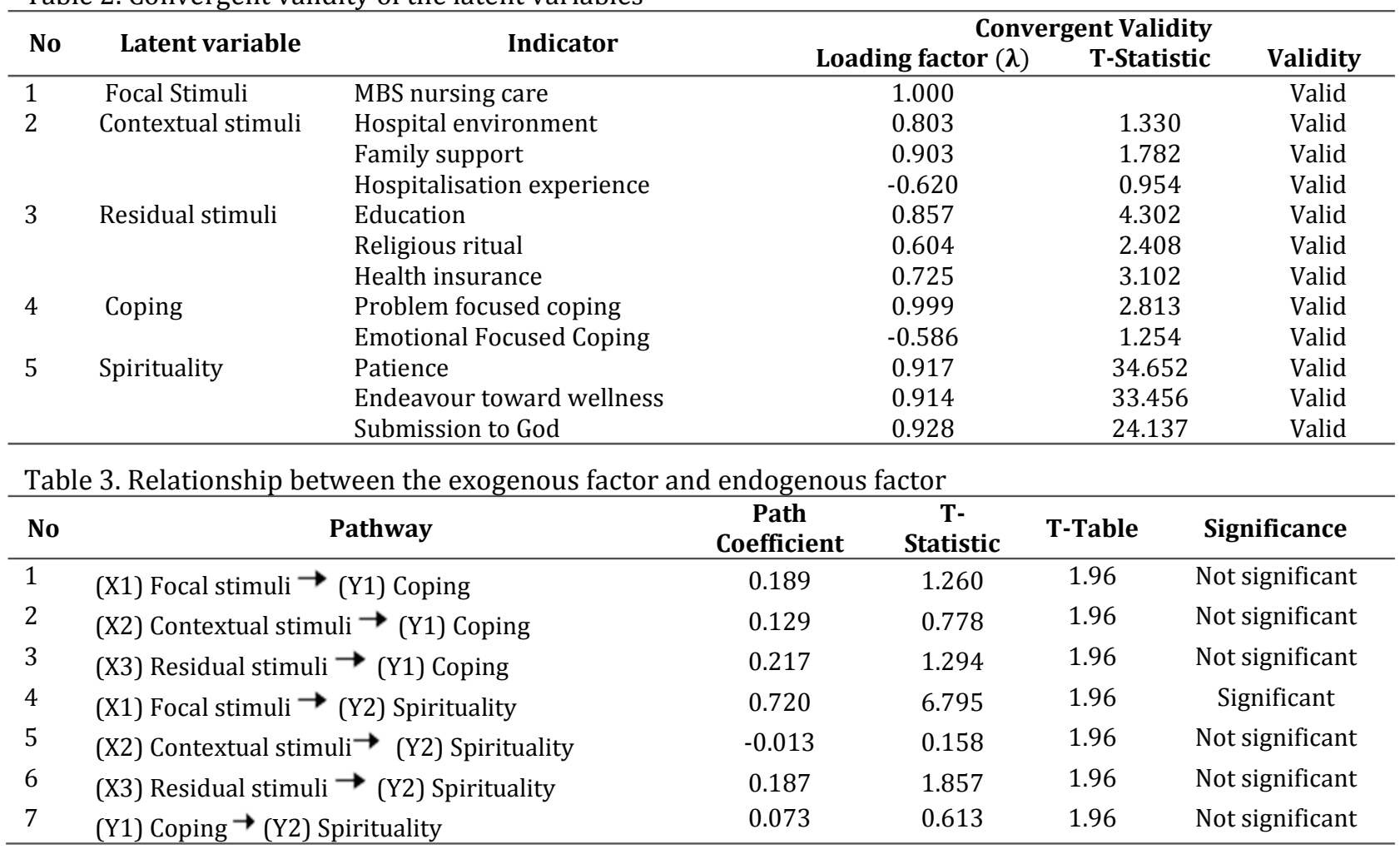

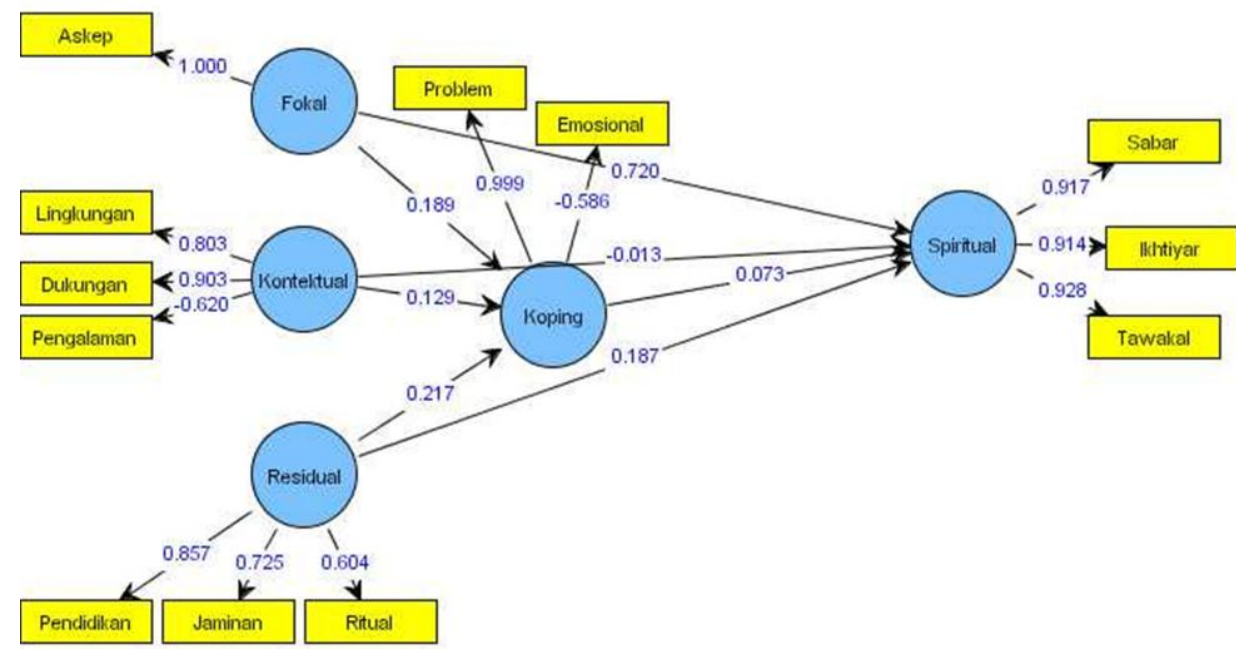

Figure 1. Mind-body-spiritual nursing care model, pathway analysis

table value $(109.025=1.96)$. Exogenous factors were considered had an effect on endogenous factors if the T-statistic value was greater than a table with fault tolerance $(\alpha)=5 \%$. The result of the significance test is described in the following table.

To develop a fit model, the structural equation model was analysed by measuring both the outer and inner model. The measurement model (outer model) was analyzed by testing the validity and reliability of the construct. As can be seen from table 4 , patients' issues and occupation were statistically not significant in defining the model, thus those two indicators were removed from the model. It can be concluded from the Table 5 that almost all exogenous variables had no significant effect on endogenous variables. Only one exogenous variable had a significant effect on an endogenous variable, namely the focal stimuli variable of spirituality.

Figure 1 illustrates the model of nursing care of MBS on the spirituality of patients treated with CHD. It can be seen from the figure that none of the exogenous factors has an influence on endogenous factors, except for the mind-body-spiritual nursing care itself (R-square value shows 0.720 ). Therefore in providing patient of CHD treated in hospital, the main focus of the nurses rely solely on the nursing care itself. The R-square value shows that the variable of spirituality can be explained by patience, 
endeavour, and submission to God by $72 \%$, while the rest explained by other factors.

To determine whether the MBS nursing care model has a good ability in predicting the improvement of someone's spirituality, the goodness of fit (GoF) test was performed and yielded a score of 0,6172 . Showing that the MBS nursing care model's ability to explain its research variables very strongly. In another word, the size of the influence of variable is big.

\section{DISCUSSION}

The results show that the focal, contextual, and residual stimuli do not have any effect on coping. Additionally, the contextual stimuli, residual stimuli, and coping also have no effect on spirituality. Only focal stimuli have a significant effect on spirituality. These findings suggest that the patients' spirituality can be enhanced directly by the provision of focal stimuli, which is the mind-body-spiritual nursing care. This is a very promising result because it highlights the strength of the study that proves the MBS nursing care may improve the patients' spirituality although other aspects of care may less favourable.

These findings are inconsistent with the previous theory that the desired adaptive response, spirituality, was not only influenced by focal stimuli, but also the contextual and residual stimuli. The results of Siyoto, Peristiowati, \& Agustin (2016) showed focal stimulus, contextual stimulus, and residual stimulus related to the coping mechanism in people living with HIV. Several studies have also shown that spirituality is related to coping of cancer patients in Iran (Abuatiq, 2015; Rezaei, AdibHajbaghery, Seyedfatemi, \& Hoseini, 2008), and African-American respondents subjected to racist treatment (Cooper, Thayer, \& Waldstein, 2014).

The limitation of the study was the efficacy of the model has not been investigated; therefore, further study is required to prove the efficacy of the model in coronary heart disease patients treated in hospitals.

\section{CONCLUSION}

Based on the results of the study can be concluded that the focal stimuli, the mind-body-spiritual nursing care, affects spirituality directly without going through coping pathways. This is very beneficial because several variables that might affect spirituality can be ignored as long as the focal stimuli can be given by the nurse properly.

However, as previously described in the discussion, this mind-body spiritual nursing care model firstly needs to be tested to patients with coronary heart disease to know its effectiveness in improving spirituality and other aspects before it can be used in clinical practice.

\section{REFERENCES}

Abuatiq, A. (2015). International Journal of Nursing \& Clinical Practices Spiritual Care for Critical Care Patients, 2, 2-5.

Asiyah, S., Putra, S., \& Kuntoro. (2011). The Increase of eHSP 72 in Members of Dzikir Group. Folia Medica Indonesiana, 47(3), 147-153. Retrieved from http://journal.unair.ac.id/downloadfullpapers-02 10026 AsiyahE_format FMI_pdf

Barnby, J. M., Bailey, N. W., Chambers, R., \& Fitzgerald, P. B. (2015). How similar are the changes in neural activity resulting from mindfulness practice in contrast to spiritual practice? Consciousness and Cognition, 36, 219232.

https://doi.org/10.1016/j.concog.2015.07.002

Cooper, D. ., Thayer, J. ., \& Waldstein, S. . (2014). Coping with racism: the impact of prayer on cardiovascular reactivity and post-stress recovery in African Ameri- can women. Ann Behav Med., 47(2), 218-230.

Kurniawati, N. ., Nursalam, \& Suharto. (2017). MindBody-Spiritual Nursing Care in Intensive Care Unit. In Advances in Health Sciences Research: 8th International Nursing Conference (Vol. 3, pp. 223228). Amsterdam: Atlantis Press.

Murray, S., Kendall, M., Grant, E., Boyd, K., Barclay, S., \& Sheikh, A. (2007). Effects-of-faith-assuranceon-cortisol-levels-are-enhanced-by-a-spiritualmantram-intervention-in-adults-with-HIV-Arandomized-trial_2009_Journal-of-P. Journal of Pain and Symptom Management, 34(4), 393-402.

Nelson, E. A., Dowsey, M. M., Knowles, S. R., Castle, D. J., Salzberg, M. R., Monshat, K., ... Choong, P. F. M. (2013). Systematic review of the efficacy of presurgical mind-body based therapies on postoperative outcome measures. Complementary Therapies in Medicine, 21(6), 697-711. https://doi.org/10.1016/j.ctim.2013.08.020

Rehatta, N. M. (2005). Pengaruh Pendekatan Psikologis Pra Bedah Terhadap Toleransi Nyeri dan Respons Ketahanan Imunologik Pasca Bedah. Universitas Airlangga. Retrieved from http://adln.lib.unair.ac.id/go.php?id=jiptunairgdl-s3-2005-rehattanan-1413\&q=rehatta

Rezaei, M., Adib-Hajbaghery, M., Seyedfatemi, N., \& Hoseini, F. (2008). Prayer in Iranian cancer patients undergoing chemotherapy. Complementary Therapies in Clinical Practice, 14(2), 90-97. https://doi.org/10.1016/j.ctcp.2008.01.001

Sholihin, M., \& Ratmono, D. (2013). Analisis SEM-PLS Dengan Wrap PLS 3.0 Untuk Hubungan Nonlinear 
Dalam Penelitian Sosial dan Bisnis. Yogyakarta: Penerbit ANDI.

Siyoto, S.-, Peristiowati, Y.-, \& Agustin, E.-. (2016). Analisis Faktor Yang Berhubungan Dengan Mekanisme Koping Pada Odha Dengan Pendekatan Teori Adaptasi Callista Roy. Jurnal Ners, 11(2), 256-260.

Vranceanu, A. M., Gonzalez, A., Niles, H., Fricchione, G., Baim, M., Yeung, A., ... Park, E. R. (2014). Exploring the Effectiveness of a Modified Comprehensive Mind-Body Intervention for
Medical and Psychologic Symptom Relief. Psychosomatics, 55(4), 386-391.

https://doi.org/10.1016/j.psym.2014.01.005

Warber, S. L., Ingerman, S., Moura, V. L., Wunder, J., Northrop, A., Gillespie, B. W., ... Rubenfire, M. (2011). Healing the heart: a randomized pilot study of a spiritual retreat for depression in acute coronary syndrome patients. Explore (New York, N.Y.), $7(4)$, 222-33. https://doi.org/10.1016/j.explore.2011.04.002 